\title{
FORMATION OF THE PROFESSIONALLY- PEDAGOGICAL COMPETENCE IN PREPARATION OF FUTURE TEACHERS IN KAZAKHSTAN
}

\author{
Meruyert Zhanguzhinova \\ Rezekne Academy of Technologies, Latvia \\ Akmaral Magauova \\ Al-Farabi Kazakh National University, Kazakhstan \\ Kaliyabanu Kertayeva \\ L. N. Gumilyov Eurasian National University, Kazakhstan \\ Dinara Yessimova \\ Pavlodar State University named after S. Toraigyrov, Kazakhstan \\ Darkhan Toktarbayev \\ L. N. Gumilyov Eurasian National University, Kazakhstan \\ Khanat Kassenov \\ L. N. Gumilyov Eurasian National University, Kazakhstan
}

\begin{abstract}
The given article is considering the problem of insufficient formulation of theoretical bases of the Formation of Professional competence of students - future teachers of Vocational training in Kazakhstan upon requirements of a new educational paradigm, this impedes the integration into the global educational space. The analysis of the theories of EU, USA and UIS scientists revealed the novelty of the research in the implementation of the main directions of international experience in accordance with the requirements of the new educational paradigm, oriented towards competencies, based on knowledge, skills and attitude. The aim of the study is to reveal the professionally-pedagogical competence for the preparation of future teachers according to the structure of using primary methods of overview-theoretical analysis, including analysis and synthesis. The study design is based on the modern requirements of higher education, based on competencies of educational paradigm. The key results of the study will determinate suggestions on the Formation of the professional competence of future teachers on the example of the specialty Vocational training. On results of theories' analyse will be revealed the structure of the professionally-pedagogical competence. The question of the study is how to improve the preparation of future teachers in Higher Educational Institutions, which is depending on modern requirements of educational paradigm based on competencies.
\end{abstract}

Keywords: preparation of future teachers, Formation of the professional competence, structure, types, activity. 
Zhanguzhinova et al., 2018. Formation of the Professionally-Pedagogical Competence in Preparation of Future Teachers in Kazakhstan

\section{Introduction}

The improvement of the quality of human capacity and provision of future Kazakhstan with highly skilled workforce is possible only under the condition of modernization of higher education in the republic, its integration into the global educational space. The field of higher education is the first priority for modern economic development of the country, since the quality of higher education predetermines sustainable competitiveness of the country in the context of the new educational paradigm.

In this regard, the overview-theoretical analysis of the competence structure will enable determination of the content of the necessary competence types, the current reform stage and the new requirements for Higher Educational Institutions of the Republic of Kazakhstan.

Particular attention must be given to the topicality of the study subject: Formation of Professional competence of students - future teachers of Vocational training, with the specialty Clothing design, in the system of higher education in Kazakhstan (Zhanguzhinova, 2018).

The aim of the study is to reveal the professionally-pedagogical competence for preparation of future teachers of the specialty Vocational training according to the structure of using primary methods of overview-theoretical analysis.

The methods of study based on theoretical analyse and review, including citation of methodological concepts, synthesis, systematization, grouping, generalization.

\section{Methodology}

The significance of the problem is the disclosure of the central nowadays idea: "science for the sector" for the formation of new specialists with human potential, and defining the economic potential of a country to a crucial extent.

The study object is the Formation of professional competence of students future teachers for their preparation in Higher Educational Institutions of Kazakhstan.

The purpose is professional preparation of competent specialists for different innovative production sectors for the fulfilment of state orders (SCES RK, 2011; The State..., 2016).

According to the "Key competences for adult learning professionals", the approved European_definition in Higher Educational Institutions of consists: knowledge, skills and attitude (Key competences..., 2010).

In the European project "Definition and Selection of Competencies" (DeSeCo), key competences are defined as "significant in many spheres of life and are the key to success in life and effective functioning of society". 
The research of the theory (Blūma, 2008; Rauhvargers, 2003; Tauril'a, 2012; 21th century..., 2016) identified that the notion of competence is related to a specific field of activity. The activity of a teacher is characterized by his ability to form student's personality, taking into consideration the limitations and conditions of educational programme (Anspoka, 2011).

Within the framework of the present article and the conducted analysis of the theory provided above the professional-pedagogical type of competence of students - future teachers of Vocational training will be considered as an essential theoretical-methodological base in professional preparation.

\section{Results and Discussion}

The study of the theories, Baumert \& Kunter (2013), Maslo \& Tillıa (2005), enabled to the structure of professionally-pedagogical competence, including: methodical, psychologically-pedagogical, differential psychological, reflection of pedagogical activity and autopsychological, special and professional types of competence (see Table 1).

Methodical competence, according to Coghlan \& Brannick (2001), is an integral characteristic of professional conditions, which includes socio-cultural, moral, humanistic education of personal and moral qualities of future teachers of Vocational training (Dzerviniks, 2016; Zogla, 2005), reflecting the content goal in functioning of methodological and methodical knowledge, skills, experience, motivation, abilities and preparedness for creative self-realization in organization of educational-methodical activity for the formation of skills to organize all pedagogical process activity types (O’Brien \& Sarkis, 2014; Zhanguzhinova, 2018).

Psychologically-pedagogical competence, according to Usca, Lubkina \& Pigozne (2012), based on professional conditions forms adequate, resultative, criterial regularity of professional and personal characteristics of a teacher, which allows to achieve qualitative results in pedagogical process (Shadrikov, 2005) and includes communicative competence (culture of communication and teaching tact), rhetorical competence (professional speech culture), cognitive competence (professional erudition) (Dolenc \& Abersek, 2015), professionally-technical competence (skill to use modern methodologies and technologies, including informationally-communicative technologies), professionally-informational competence (ability to carry out pedagogical diagnostics) (Epstein \& Hundert, 2002), reveals in assessment judgements in pedagogical activity that forms social characteristics of a personality of future teachers of Vocational training (Gaveika, 2016; Zhanguzhinova, 2018). 
Zhanguzhinova et al., 2018. Formation of the Professionally-Pedagogical Competence in Preparation of Future Teachers in Kazakhstan

Table 1 The structure of professionally-pedagogical competence for preparation of future teachers

\begin{tabular}{|c|c|c|c|c|c|}
\hline 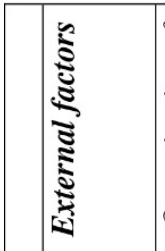 & 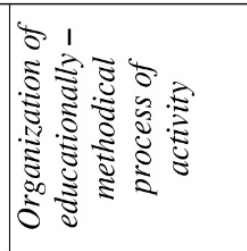 & 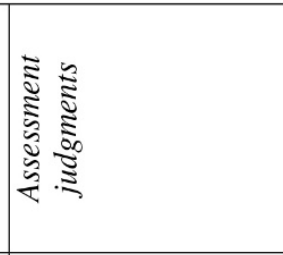 & & 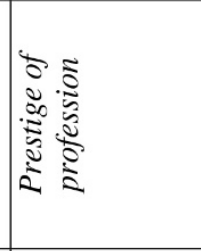 & 芯 \\
\hline 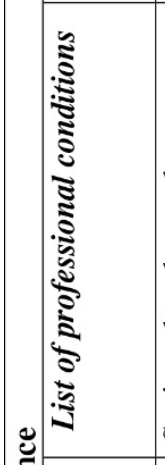 & 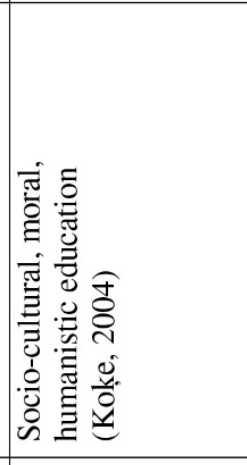 & 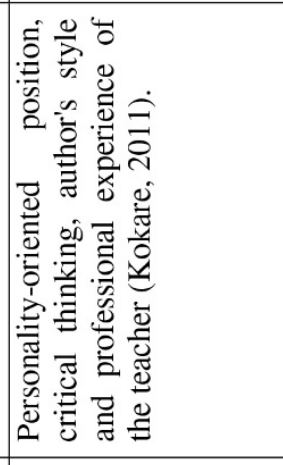 & 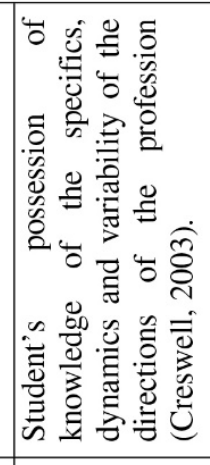 & 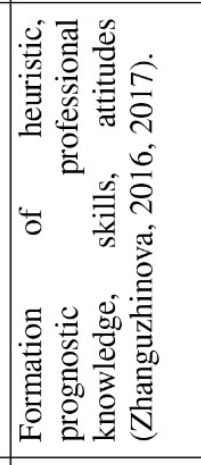 & 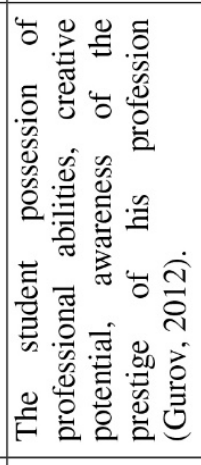 \\
\hline 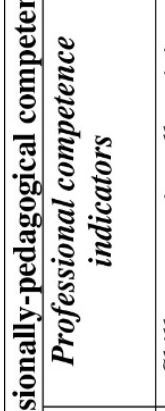 & 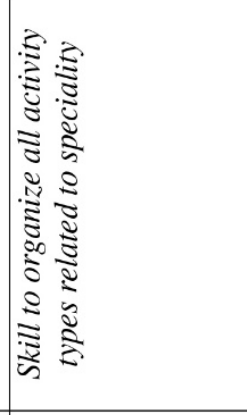 & 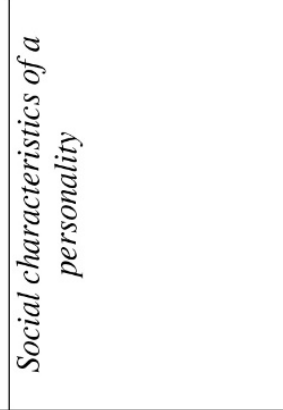 & 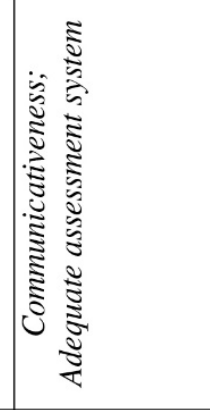 & 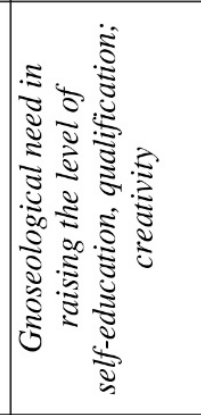 & 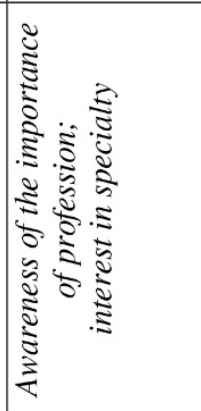 \\
\hline 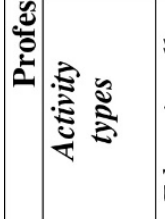 & 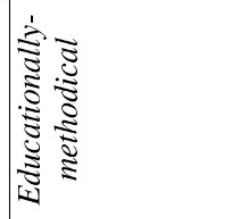 & 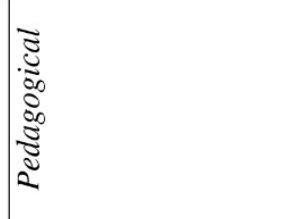 & 密 & 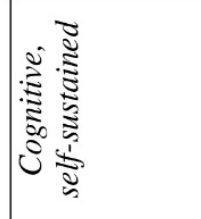 & $\mid$ \\
\hline 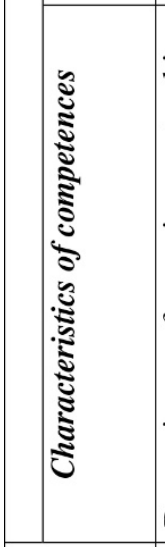 & 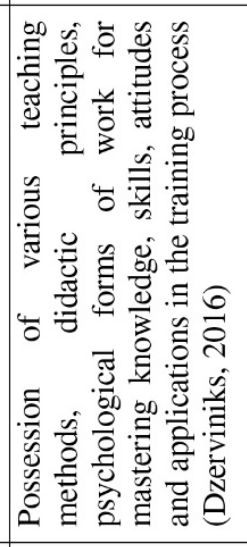 & 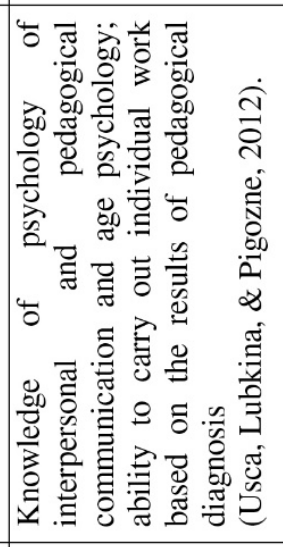 & 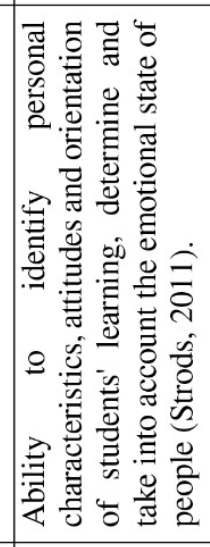 & 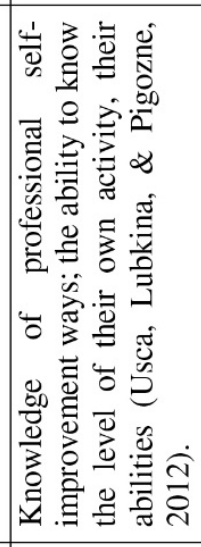 & 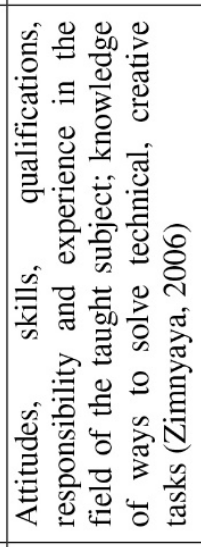 \\
\hline 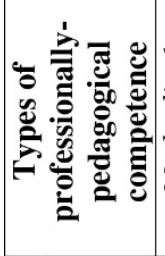 & & 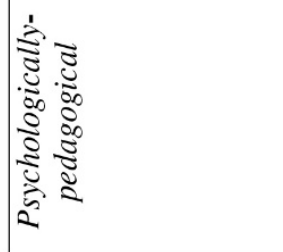 & 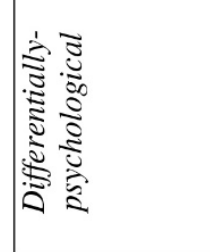 & 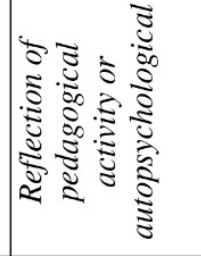 & 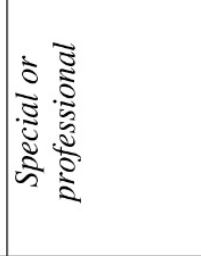 \\
\hline
\end{tabular}


Differentially-psychological competence, according to Andersone (2009), comprises of the knowledge of a teacher on individual psychological characteristics of each student. Intensity of differential psychological competence formation depends on professional conditions. These enable to form criteria' levels, to reveal the results of the possession of teaching subject and information in the specifics, dynamics and variability of the directions of the profession (Dzerviniks, 2016), orientation type and ability of special, methodical and psychologically-pedagogical, and autopsychological competencies (Maslo \& Till,a, 2005) on the basis of assessment judgements in teaching activity, forms communicativeness and adequate assessment system (Zhanguzhinova, 2018).

The reflection of pedagogical activity or autopsychological competence, according to Zogla (2005), is the most essential element of self-awareness, formed on the base of activity' organization of future teachers of Vocational training. Professional conditions are focused on the formation of heuristic, prognostic knowledge, skills, attitudes and self-improvement of the specialist (Kokge, 2002). Dependence of cognitive and self-sustained types of activity, based on the assessment judgments on the awareness of the profession's prestige forms gnoseological need to raise the level of self-education, qualification, creativity (Adubra, 2014; Atkinson, 2004; Zhanguzhinova, 2018).

Special and Professional competence, based on the definition of Khmel (1998), determined by professional conditions of unity of content and goal on theoretical and practical preparedness of a teacher in the fulfilment of professional functions. Competence is integrated in the professional and personal characteristics of a teacher and defines a training trajectory (Anspoka, 2011), acquisition of knowledge (Rychen \& Tiana, 2004) and purposeful application in prediction, planning and realization of activity (Cassidy \& Eachus, 2000). Activation of a teacher in the development of his own abilities (Burleson, 2005), desire for self-realization in socially beneficial activity (Zimnyaya, 2006) provides professional development of a future specialist already during the training period in HEI and in practice (Epstein \& Hundert, 2002). The productivetechnological activity forms awareness of the importance of the profession and interest in the specialty (AE-pro, 2015).

The analysis of the theories provided above revealed the structure of the professionally-pedagogical competence (Zhanguzhinova, 2018), including:

- types (methodical competence, psychologically-pedagogical competence, differentially-psychological competence, reflection of pedagogical activity or autopsychological competence, special or professional competence);

- characteristics of competence, based on the scientists' conceptions presented above; 
Zhanguzhinova et al., 2018. Formation of the Professionally-Pedagogical Competence in Preparation of Future Teachers in Kazakhstan

- activity types (educationally-methodical, pedagogical, training, cognitive, self-sustained, productive technological) based on the research regarding the organization of students-future teachers' activity;

- formation of Professional competence indicators;

- list of professional conditions based on the scientists' conceptions presented above;

- $\quad$ external factors (organization of educationally-methodical process of activity, assessment judgements, the prestige of profession, practice), which are evidence of the results on the basis of the criteria for the Formation of Professional competence (Zhanguzhinova, 2018).

\section{Conclusions}

Thus, the analysis of the theories enabled to conclude that the modern stage of the Formation of professional competence of students - future teachers of Vocational Training in Kazakhstan reflects the new educational paradigm, based on the implementation of innovative processes in education in interaction with production.

In order to improve the preparation of specialists based on the integration of new knowledge, skills and attitude, based on innovative technologies and production, it is necessary:

- $\quad$ to consider the types of professionally-pedagogical competence;

- to develop competences and their characteristics in organizing the educational process in a university and practice;

- to create the criteria of the Formation of professional competence based on the revealed Professional competence indicators in accordance with the development of Modular Educational programmes in HEI;

- to make additions to educational programmes taking into account the need for practice, based on the revealed activity types;

- to organize work on course projects in designing specialties with determining the list of professional conditions and external factors during each semester with real topics, for real customers;

- to create a single data bank in order to systematize the registration of graduates and interact with employers for an interactive search for jobs on-line with the introduction of the applicant's data on his professional competences. 


\section{References}

Adubra, E. (2014). Fragmentation of teacher Education: Responses from the teacher Task Force Network. Teacher Education Policy in Europe Network, 124. Zagreb: UNESCO. Retrieved from https://www.idi.hr/tepe2014/eadubra.pdf

Atkinson, D. (2004). Theorizing How Student Teachers Form Their Identities in Initial Teacher Education. British Educational Research Journal, 30 (3), 379-394.

AE-pro. (2013). European Adult Education (Young) Professionals learning Platform. European Association for the Education of Adults. Retrieved from https://www.aelearning.eu/

Andersone, R. (2009). Teachers' professional competence for sustainable development of society. Pedagogy and Teacher Education. U.S. articles. 747. Riga: University of Latvia Academic Publishing.

Anspoka, Z. (2011). Teaching tool and pupil's learning competence. Riga: RaKa.

Baumert, J., \& Kunter, M. (2013). The COACTIV Model of Teachers' Professional Competence, Springer.

Blūma, D. (2008). Teacher Education in the Context of the Bologna Process. ATEE Spring University Teacher of the 21st century: Quality education for quality teaching, 673 - 680. Riga: LU.

Burleson, W. (2005). Developing creativity, motivation, and self-actualization with learning systems. International Journal of Human - Computer Studies, 63 (4-5), 436 - 451. doi: 10.1016/j.ijhcs.2005.004.007

Cassidy, S., \& Eachus, P. (2000). Learning style, academic belief systems, self-report student proficiency and academic achievement in higher education. Journal of Educational Psychology, 20 (3), 307-322. Retrieved from http://dx.doi.org/10.1080/713663740

Coghlan, D., \& Brannick, T. (2005). Doing Action Research in Your Own Organization, 157. 11-15. LosAngeles, London, NewDelhi, Singapoure: SagePublications.

Creswell, J. W. (2003). Research Design. Qualitative, Quantitative, and Mixed Methods. Approaches, 2 (246). SAGE Publications. Curzon, L.B. (2008). Teaching in Further Education. An Outline of Principles and Practice, 6 (459). London. New York: Continuum.

Dolenc, K., \& Abersek, B. (2015). Intelligent and adaptive e-learning system: Integration into Technology and Science classrooms in lower secondary schools. TECH8. Computers \& Education, 82. 354e365.

Dzerviniks, J. (2016). Teacher training in the context of inclusive education: methodological dimension. Proceedings of the International Scientific Conference Society. Integration. Education, 1. Rezekne: RTA. DOI: http://dx.doi.org/10.17770/sie2016vol1.1501

Epstein, R. M., \& Hundert, E. M. (2002). Defining and Assessing Professional Competence. JAMA, 287 (2), 226-235.

Gaveika, A. (2016). Personality Development, Education and Competence as Basic Elements of Creativity. Proceedings of the International Scientific Education. Integration. Education, 1, 48. DOI: http://dx.doi.org/10.17770/sie2016vol4.1546

Gurov, V. N. (2012). Features of the functioning and development of the MPE system in modern conditions. The bulletin of the faculty of advanced training SSU, 2. Stavropol.

Gurye, L. I. (2009). Teachers of the University for the Innovative professional-pedagogical Activity. Higher education in Russia, 2, 91-95.

Khmel, N. D. (1998). Theoretical bases of teacher training. Almaty, Scientist 
Zhanguzhinova et al., 2018. Formation of the Professionally-Pedagogical Competence in Preparation of Future Teachers in Kazakhstan

Kokare, M. (2011). Learning in the organization as a perspective of the pedagogical process. (Doctoral dissertation). Retrieved from https://luis.lu.lv/pls/pub/wct.doktd?l=1

Koḳe, T. (2002). Pedagogical basics of lifelong learning. Teacher, 2 (32), 4 - 6.

Key competences for adult learning professionals. (2010). Contribution to the development of a reference framework of key competences for adult learning Professionals. Final report. Project number: B3542. Retrieved from http://eprints.gla.ac.uk/54184/

Maslo, I., \& Tiḷlla, I. (2005). Competence as a perfect and analytical category of upbringing. Teacher, 3 (52). 4- 9.

O’Brien, W., \& Sarkis, J. (2014). The potential of community-based sustainability projects for deep learning initiatives. Journal of Cleaner Production, 62. 48e61.

Rauhvargers, A. (2003). Latvia in the Bologna process. Report on the progress of the reform of Latvia's higher education towards the European Single Area of Higher Education The Secretary General of the Latvian Rectors' Council, 17. The Latvian Council of Rectors. Riga: Academic Information Center. Retrieved from http://www.aic.lv/bolona/ Latvija/LV_Bol_lv.pdf

Rychen, D. S., \& Tiana, A. (2004). Developing key competences in education: some lessons from the international and national experience, 12-15. UNESCO Publishing, France.

Shadrikov, V. D. (2005). New model of specialist: innovative training and competence approach. Higher education today, 8, 9 - 23.

Strods, G. (2011). Development of Self-directed Learning Concept. Proceedings of the International Scientific Conference Society. Integration. Education, 288-298.

Tauringa, T. (2012). Dimensions and diversity of methods of measurement of adult competences. Mārtinsone, K. Pieaugušo izglìtība, 115-129.

SCES RK. (2011). The state compulsory standard of education of the Republic of Kazakhstan is higher education. Undergraduate. 5.04.019. Astana: Ministry of Education and Science of the Republic of Kazakhstan.

The State Program for the Development of Education and Science of the Republic of Kazakhstan for 2016-2019. (2016). Astana: Ministry of Education and Science of the Republic of Kazakhstan. Retrieved from http://control.edu.gov.kz/ru/ob-utverzhdeniiplana-meropriyatiy-po-realizacii-gosudarstvennoy-programmy-razvitiya-obrazovaniya-i

Usca, S., Lubkina, V., \& Pigozne, T. (2012). A Model of Developing Communicative Competence for the Needs of Adolescents with Language Disorders. International conference on Financial, Management and Education Science, 44-52.

Zhanguzhinova, M. Y. (2018). Formation of the Professional competence of students - future (Doctoral dissertation). Retrieved from http://dspace.lu.lv/dspace/bitstream/handle/ 7/37903/298-62696-Zhanguzhinova_Meruyert_mz16017.pdf?sequence=1

Zhanguzhinova, M. Y. (2017). Formation of the Professional competence of students - future teachers of Vocational training in the system of higher education in Kazakhstan. Proceedings of the International Scientific Conference Society. Integration. Education, 1, 275-285.

Zhanguzhinova, M. Y., Magauova, A. S., \& Nauryzbaeva, A. S. (2016). Competence approach in Vocational education of Kazakhstan in conditions of innovational and industrial development of the society. Proceedings of the International Scientific Conference Rural Environment. Education. Personality. Proceedings of the International Scientific Conference, 9, 128-133. 
Zimnyaya, I. A. (2006). Competency approach. What is his place in the system of modern approaches to education? (theoretical and methodological aspect), 4. Moscow: Higher education today.

Zogla, I. (2005). Teacher educators' pedagogical action competence to sustain students' learning. In A. Slahova (Ed.). Scientific articles of the Fourth International conference Person. Color. Nature. Music, 90-101.

21th century competencies. (2016). Journal Independent school, 70. Retrieved from http://www.edugains.ca/resources21CL/About21stCentury/21CL_21stCenturyCompete ncies.pdf 